\title{
Comparative Analysis of Household Consumption Pattern of Local and Imported Rice in Ekiti State, Nigeria
}

\author{
Oseni Joseph Olumide \\ Department of Agricultural Economics and Extension, Federal University of Technology, PMB, 704, Akure, Ondo State, Nigeria
}

Received: April 9, 2011 / Accepted: April 5, 2015 / Published: April 30, 2015.

\begin{abstract}
The paper examined the consumption pattern and attitude of households for local and imported rice in Ekiti State, Nigeria. The specific objectives of the paper are to: examine the household preference and consumption level of local and imported rice, examine price variation between local and imported rice and identify the major problems confronting marketers of local and imported rice. Data were collected from 100 randomly chosen households with the aid of structured questionnaire. Data collected were analyzed with the use of descriptive statistics such as frequency, percentages, chi-square, $t$-test and regression analysis. The paper revealed among others that majority of the respondents prefer to consume local rice to imported rice because of its more palatability, health benefits, readily availability and relatively cheap price. The average price per kilogramme of local rice is 200 Naira compared to that of imported rice which is 300 Naira. The difference in price is as a result of exchange rate and costs associated with smuggling of imported rice across the border of Nigeria from neighbouring countries. Nonetheless, the quality of local rice is still very low when compared to imported rice in terms of degree of impurities such as stone and shafts and the level of polishing.
\end{abstract}

Key words: Comparative, analysis, rice, marketing, pattern, attitude, consumption.

\section{Introduction}

Rice is the most nutritious and highly valued cereal in Nigeria. It's a source of sugar, water-soluble vitamins and minerals, which are important in body building. In addition to using rice as food, the grain is used for the manufacturer of starch, sauces and vinegar. The balls are used in building materials, for insulating and in polishing industrial soap [1].

Rice is grown in virtually all the agro ecological zone in Nigeria. Despite this, the area cultivated to rice still appears. Rice is an increasingly important crop in Nigeria. It is relatively easy to produce and is grown for sale and for home consumption. In some areas there is a long tradition of rice growing, but for many rice has been considered a luxury food for special occasions only. With the increased availability of rice, it becomes part of the everyday diet of many

Corresponding author: Oseni Joseph Olumide, Ph.D., research field: agricultural marketing. E-mail: oseni156@yahoo.com. in Nigeria [2].

Rice production started in Nigeria in $1500 \mathrm{BC}$ with the low yielding indigenous red grain species $\mathrm{O}$. Glaberina (steud), then widely grown in the Niger Delta area. The high yielding white grain $\mathrm{O}$. sativa was introduced in about 1890, and by 1960 it accounted for more than $60 \%$ of the rice grown in the country [3].

The demand for rice in Nigeria has been soaring at a very fast rate over the years [4]. A combination of various factors seems to have triggered the increase in rice consumption. According to Douangboupha, B. K. et al. [5], rising demand was partly the result of increasing population growth. Also increased income levels following the discovery of crude oil led to use in the demand for the commodity.

Rice imports have affected the domestic production and marketing of Nigeria's local rice. This is due to the decreased demand for local rice by Nigerians as opposed to the imported ones. The local Nigerians 
varieties have a lower demand due to the high cost of producing the crop and cost of production is usually not subsidized by the government. The non-competitiveness could also be as a result of poor processing resulting in a final product with a high percentage of broken grains and debris [6].

The increasing preference for rice in the diet of Nigerians is attested to by the ever-rising import bill of rice by Nigeria. Ekiti State is one of the states in Southwest zone of Nigeria, which is producing the least quantities of rice. This zone, being more mechanized than other zones of the country, also consumed more of imported rice, because urbanization is one of the major reasons for the shift from traditional foods to mainly rice. Ekiti State is therefore one of the states unnecessarily wasting her resources on rice importation, since this state has one of the highest potentials for producing rice.

The major objective of this paper is to investigate household consumption pattern of local and foreign rice in Ekiti State.

The specific objectives of the paper are to: examine the socio-economic characteristics of the respondents, determine the household preference and consumption level of local and foreign rice, determine the demand for local and foreign rice by household in Ekiti State, determine the price variations between local and foreign rice in Ekiti State and identify the problems encountered by the local farmers in rice production.

Marketing is the performance of all business activities involved in the flow of goods and services from the point of initial production until they are in the hands of the ultimate consumers at the right time, in the right place and as convenient as possible, at a profit margin so as to keep the farmer in his farming operations [7]. The marketing of local rice could be into four stages with a change of product ownership occurring between each pair of stages alone. Per caput rice consumption rose from $3.5 \mathrm{~kg}$ in 1970 to more than $14 \mathrm{~kg}$ in the 1990s. This phenomenon was largely the result of increased per caput income, rapid population growth and changes in the tastes and diet of Nigerians.

\section{Research Methodology}

The study was carried out in Irepodun/Ifelodun Local Government Area of Ekiti State Nigeria. Ekiti State is a state in Southwest Nigeria, created on October 1, 1996. The state was, created out of the former Ondo State. However, on creation, it took off with sixteen (16) LGA (Local Government Areas) and 34 towns spread around the state. Ekiti State is one of the 36 states (including the Federal Capital Territory, Abuja) that constitute Nigeria. The selected areas are predominantly Yoruba speaking tribes. The climate encourages the growth of forest, vegetation which makes the areas blessed with vast area of forest land and there is high relative humidity. The traditional food crops grown include: rice, maize, beans, yam, plantain and cassava etc., and the cash crop includes cocoa rubber, oil palm.

Multi-stage sampling technique was used in selecting the respondents. The first stage involved the purposive selection of Irepodun/Ifelodun Local Government Area being the leading rice producing Local Government Area. At the second stage, two communities Awo Ekiti and Igbemo Ekiti were purposively chosen from Irepodun/Ifelodun Local Government in Ekiti State. At the third stage, five wards were randomly selected from each selected community given a total of 20 wards. Finally, five respondents were randomly selected from each ward making a total of 100 respondents for the study.

The data used in present study were primary and secondary data. The primary data were collected through the use of well structured questionnaire which was administered on local rice and imported rice consumers while the secondary data were collected from journals, textbooks, Ministry of Commerce and Industry.

The analytical technique used in present study 
includes: descriptive statistics such as frequencies tables and percentage to examine the socio-economic characteristics of the consumers of local and foreign rice.

The chi-square technique was used to test whether the observed frequency is significantly different from the expected frequency.

The hypothesis is specified as:

$$
\chi^{2}=\frac{\sum(O-E)^{2}}{E}
$$

Where, $\chi^{2}=$ Chi-square at $(C-1)(R-1)$ degrees of freedom;

$$
\begin{aligned}
& O=\text { Observed frequency; } \\
& E=\text { Expected frequency; } \\
& \Sigma=\text { Summation sign; } \\
& C=\text { No of columns; } \\
& R=\text { No of rows. }
\end{aligned}
$$

The $t$-statistic was used to determine whether there is any significant difference in the consumer preference for foreign and local rice.

$$
t=\frac{X-\mu}{\sqrt{\frac{S}{\eta}}}
$$

\section{Results and Discussions}

This section contains findings from the survey carried out to assess the attitude of consumer's consumption pattern to local and foreign rice production in Ekiti State.

Table 1 showed the type of rice which is highly preferred by the respondents, it reveals that majority of the respondents $(74.0 \%)$ preferred local rice while only $26 \%$ of the respondents preferred foreign rice.

As shown in Table 2 and Table 3, it could be seen that the modal reason for consuming local rice is that it is more palatable as attested to by $52 \%$ of the respondents. Next reason to this is that it is readily available as attested to by $20 \%$ of the respondents while just $2.0 \%$ of the respondents said it is cheaper.

Tables 4-7 revealed that the modal monthly income of respondents ranges between 20,000-29,000 Naira as

Table 1 Type of rice consumed by respondents.

\begin{tabular}{lll}
\hline Type of rice & Frequency & Percentage \\
\hline Local rice & 74 & 74.0 \\
Imported rice & 26 & 26.0 \\
Total & 100 & 100.0 \\
\hline
\end{tabular}

Source: Field Survey, 2010.

Table 2 Distribution of respondents according to reasons for consumption of local rice.

\begin{tabular}{lll}
\hline Reasons for consumption of local rice & Frequency & Percentage \\
\hline More palatable & 52 & 52.0 \\
Cheaper & 2 & 2.0 \\
Readily available & 20 & 26.0 \\
Others that do not consume local rice & 26 & 26.0 \\
Total & 100 & 100.0 \\
\hline
\end{tabular}

Source: Field Survey, 2010.

Table 3 Distribution of respondents according to reasons for consumption of imported rice.

\begin{tabular}{lll}
\hline Reasons for consumption of foreign rice & Frequency & Percentage \\
\hline More palatable & 10 & 10.0 \\
Cheaper & 3 & 3.0 \\
Readily available & 13 & 13.0 \\
Others that did not consume imported rice & 74 & 74.0 \\
Total & 100 & 100.0 \\
\hline
\end{tabular}

Source: Field Survey, 2010. 

Imported Rice in Ekiti State, Nigeria

Table 4 Distribution of respondents according to their monthly income.

\begin{tabular}{lll}
\hline Monthly income in Naira & Frequency & Percentage \\
\hline$<10,000$ & 18 & 18.0 \\
$10,000-19,000$ & 24 & 24.0 \\
$20,000-29,000$ & 32 & 32.0 \\
$30,000-39,000$ & 12 & 12.0 \\
Above 39,000 & 4 & 4.0 \\
Total & 100 & 100.0 \\
\hline
\end{tabular}

Source: Field Survey, 2010.

attested to by the respondents while just only $4 \%$ of the respondents earned above 39,000 Naira as monthly income.

From Table 8, many of the respondents (46.0\%) very much preferred local rice to imported rice while $20.0 \%$ of them just preferred it. Only $8.0 \%$ of the respondents are much preferred, $18 \%$ of the respondents did not prefer and the remaining $(8.0 \%)$ of them did not very much prefer local rice to imported rice

From Tables 9-12, many of the respondents (50.0\%) are facing problems of irregular supply alone for rice consumers and marketers, which is followed by $36.0 \%$ of the respondents facing problem of price fluctuations, respondents facing problems of loss due to spoilage $(10.0 \%)$ while $4.0 \%$ of respondents are facing the problems of poor demand.

Table 5 Amount spent on feeding per month by the respondents.

\begin{tabular}{lll}
\hline Amount spent on feeding in Naira & Frequency & Percentage \\
\hline 5,000 & 50 & 50.0 \\
10,000 & 17 & 17.0 \\
15,000 & 11 & 11.0 \\
20,000 & 17 & 17.0 \\
Above 20,000 & 5 & 5.0 \\
Total & 100 & 100.0 \\
\hline
\end{tabular}

Source: Field Survey, 2010.

Table 6 Amount spend on feeding of local rice.

\begin{tabular}{lll}
\hline Amount spent on feeding of local rice in Naira & Frequency & Percentage \\
\hline 2,000 & 57 & 57.0 \\
4,000 & 17 & 17.0 \\
6,000 & 17 & 17.0 \\
8,000 & 9 & 9.0 \\
Total & 100 & 100.0 \\
\hline
\end{tabular}

Source: Field Survey, 2010.

Table 7 Amount spend on feeding of imported rice.

\begin{tabular}{lll}
\hline Amount spent on feeding of Imported rice in Naira & Frequency & Percentage \\
\hline 2,000 & 32 & 32.0 \\
4,000 & 22 & 22.0 \\
6,000 & 22 & 22.0 \\
8,000 & 14 & 14.0 \\
Above 8,000 & 10 & 10.0 \\
Total & 100 & 100.0 \\
\hline
\end{tabular}

Source: Field Survey, 2010. 
Table 8 Distribution of respondents according to their preference of local rice to imported rice.

\begin{tabular}{lll}
\hline Responses & Frequency & Percentage \\
\hline Very much preferred & 46 & 46.0 \\
Much preferred & 8 & 8.0 \\
Just preferred & 20 & 20.0 \\
Not preferred & 18 & 18.0 \\
Very much un-preferred & 8 & 8.0 \\
Total & 100 & 100.0 \\
\hline
\end{tabular}

Source: Field Survey, 2010.

Table 9 Distribution of respondents according to the major problems faced in rice marketing of both local and imported rice.

\begin{tabular}{lll}
\hline Major problems & Frequency & Percentage \\
\hline Poor demand & 4 & 4.0 \\
Irregular supply & 50 & 50.0 \\
Loss due to spoilage & 10 & 10.0 \\
Price fluctuations & 36 & 36.0 \\
Total & 100 & 100.0 \\
\hline
\end{tabular}

Source: Field Survey, 2010.

\section{Regression Analysis Result}

The regression equation that shows the relationship between income and consumption of rice is $Y=1.204$ $+0.525 x$

$$
Y=\text { consumption, } x=\text { income. }
$$

The equation shows high reliability as $R^{2}$ is $54 \%$.

\section{Chi-Square Analysis Result}

It has been discovered that income is the main determinant of the quantity of any product an individual will purchase. The result revealed that the null hypotheses of the present paper which states that: there is no significant relationship between the quantities of local and foreign rice consumed and the income of the household should be rejected. The result of the chi-square analysis shows that the quantity of local rice consumed in the households depend on the income of the household in Table 13.

\section{Summary, Conclusion and Recommendations}

The paper revealed among others that, majority of the farmers $(30 \%)$ were below 60 years of age. This shows that there were more youths in the study area, also most of the respondents are male (64\%). This implies that most of the respondents in the study area were married $(66 \%)$. The study also revealed that Christianity is the dominant religion in the study area as attested to by $60 \%$ of the respondents. Also from the study, majority of the respondents were learned people who could read and write and take reasonable decision and understand the result and implications of their decisions.

$46 \%$ of the respondents have a total family size ranging from 6-10, meaning that majority of the respondents in the study area have a moderate family size. The paper also revealed the income range of the respondents showing that most of the respondents earned 20,000-29,000 Naira per month. This might be due to the fact that majority of the respondents are either government workers or medium scale farmers. This shows that the socio economic characteristics of the respondents in the study area favoured the consumption of local rice.

Majority of the respondents in the study area consumed local rice $(74 \%)$. This implies that local rice is a major source of food in the study area.

Majority of the respondents $(86 \%)$ consumed local rice because it's more palatable. This means that most 
Table 10 ANOVA ${ }^{\mathrm{b}}$.

\begin{tabular}{lllllll}
\hline Model & & Sum of squares & Df & Mean square & F & Sig. \\
\hline 1 & Regression & 14.700 & 1 & 14.700 & 16.523 & $.000^{\mathrm{a}}$ \\
& Residual & 35.586 & 40 & .890 & & \\
& Total & 50.286 & 41 & & & \\
\hline
\end{tabular}

a Predictors: (Constant), Consumption of local rice.

b Dependent Variable: Income.

\section{Scatterplot}

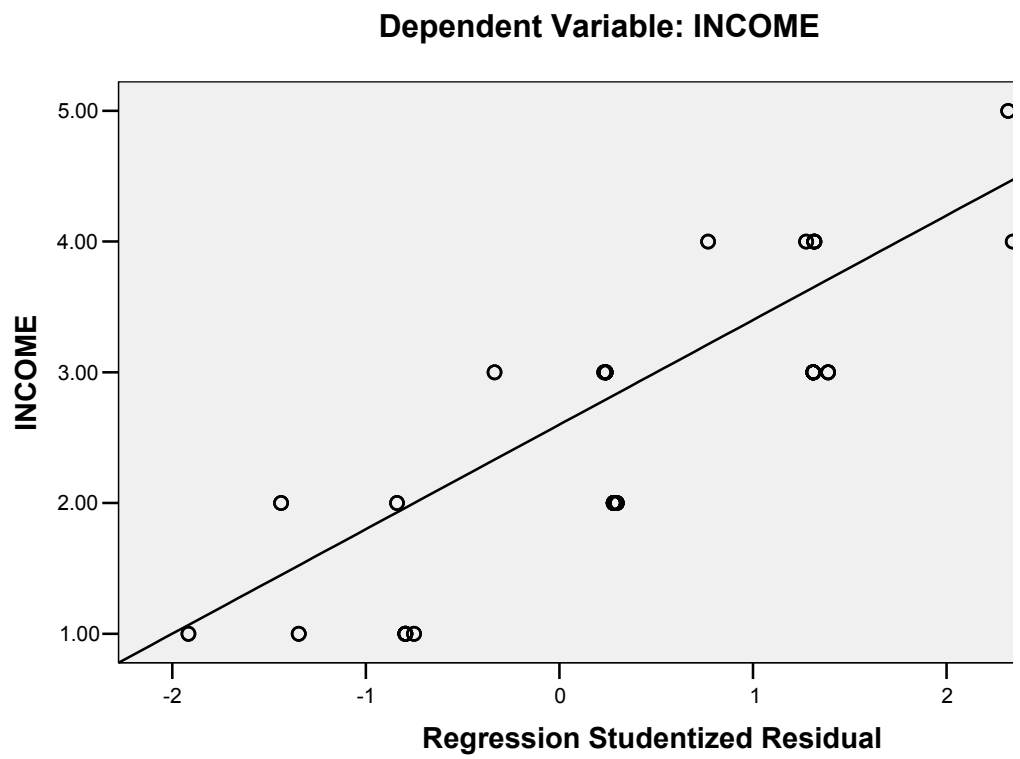

Table 11: Selling price of local rice per kongo.

\begin{tabular}{llll}
\hline Selling price of local rice in Naira & Observed frequency N. & $\begin{array}{l}\text { Expected frequency } \\
\text { N. }\end{array}$ & Residual \\
\hline Less than 300 & 22 & 47.0 & -25.0 \\
300 and above & 72 & 47.0 & 25.0 \\
Total & 94 & & \\
\hline
\end{tabular}

Table 12: Selling price of imported rice per kilogramme.

\begin{tabular}{llll}
\hline Selling price of imported rice per & Observed frequency & Expected frequency & Residual \\
kongo in Naira & 88 & 50.0 & 38.0 \\
\hline less than 300 & 12 & 50.0 & -38.0 \\
300and above & 100 & & \\
Total & & \\
\hline
\end{tabular}

Table 13: Chi-square test statistics.

\begin{tabular}{lll}
\hline & Selling price of local rice per kongo & Selling price of imported rice per kongo \\
\hline Chi-Square & 26.596 & 57.760 \\
Df & 1 & 1 \\
Asymp. Sig. & .000 & .000 \\
\hline
\end{tabular}

a 0 cells $(.0 \%)$ have expected frequencies less than 5 . The minimum expected cell frequency is 47.0 .

b 0 cells $(.0 \%)$ have expected frequencies less than 5 . The minimum expected cell frequency is 50.0 . 


\section{Comparative Analysis of Household Consumption Pattern of Local and Imported Rice in Ekiti State, Nigeria}

of the respondents in the study area see local rice as a delicacy.

The major conclusion that can be drawn from the present paper is that majority of the respondents prefer to consume local rice as compared to imported rice because it is more palatable, cheaper and readily available.

Based on the findings of their study, the following recommendations were made:

(1) New improved technology should be made known to local rice farmers to adopt by the extension workers.

(2) Local rice farmers should form and join cooperative societies so as to take advantage of economies of large scale production of rice.

(3) More attentions should be paid to agriculture by making it attractive to the youths so that they can replace the older generation that is aging.

(4) Since the consumers of local rice are attracted by people should be enlightened on the benefits of consuming local rice.

\section{References}

[1] Daramola, A. G. 2004. "Competitiveness of Nigeria Agriculture in a Global Economy: Any Dividends of Democracy?" Inaugural Lecture Series 36. Federal University of Technology Akure.

[2] Godwin, A. 2001. West Africa Rice Development Association (WARDA) Bouake Cote d 'ivoire. Report.

[3] Imolehin, E. D. 1991. Rice Improvement and Production in Nigeria. Presented at WARDA Upland Breeding Task-Force Bouake Cote d'ivoire, Report..

[4] John, G. C., Litsinger, J. A., Chen, Y., and Barrison, A. 2001. Integrated pest management $C A B$ International .

[5] Douangboupha, B. K., Khanphoukeo, S., Inthavong, J., Schiller, J., and Jahn, G. 2006. Pest and Diseases of the Rice Production System. London: Macmillan publishers.

[6] Singh, B. N., Fagade, S., Unkwungwu, M. N., Williams, C., Jagtap, S. S., and Olademeji, O. 1997. "Rice Growing Environments \& Biophysical Zones of Nigeria." Met. J. 2 (1): $35-44$

[7] National Research Council. 1996 Africa Rice. Nigeria: National Academy press. 